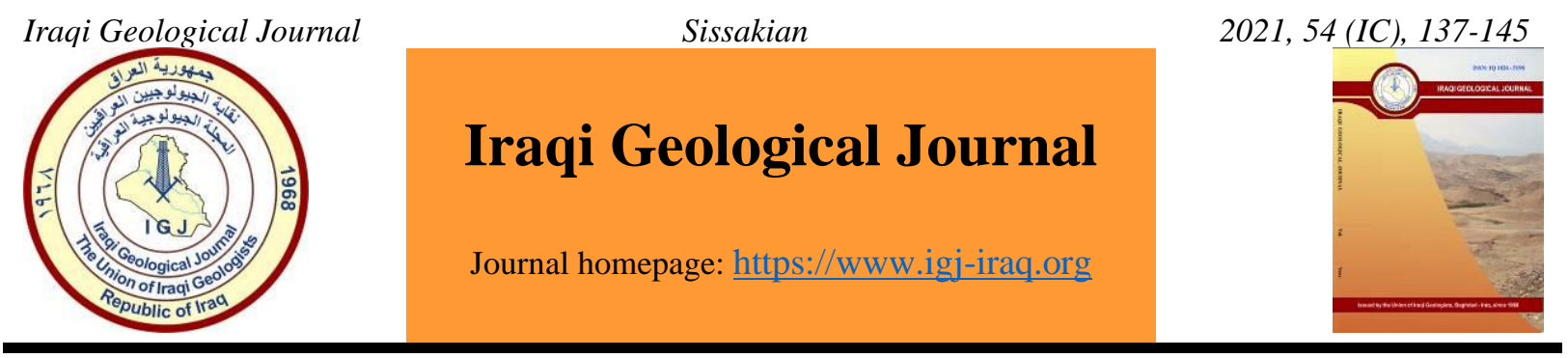

\title{
Shanidar Cave in Northern Iraq (Kurdistan Region), a National Geopark Recommendation
}

\author{
Varoujan K. Sissakian ${ }^{1, *}$ \\ ${ }^{1}$ Department of Natural Resources Engineering and Management, University of Kurdistan Hewler, Erbil, Iraq \\ *Correspondence: f.khajeek@ukh.edu.krd; varoujan49@yahoo.com
}

Received: 12 November 2020; Accepted: 20 January 2021; Published: 31 March 2021

\begin{abstract}
Shanidar Cave is located in north Iraq (Kurdistan Region), it is one of the most well-known caves in the region due to its archeological significance. It is an archaeological site which is located within Bradost Mountain north of Erbil city. In the cave, eleven skeletons of Neanderthals, have been found dating back to $65000-35000$ years B.C., they were called Shanidar (1-11). The cave also contains two later proto-Neolithiccemeteries. The cave is developed due to dissolution of limestone beds of the Qamchuqa Formation which forms the carapace of Bradost Mountain (anticline). Currently, the cave and the downslopes to the foothills of the mountain are limited by a fence. The cave can be reached by a paved road to the foothills level, then by stepping following artificially constructed leader which is designed and constructed by local materials from stones and wood giving to the leader a natural view. The Shanidar cave is highly recommended to be a national Geopark due to its archeological significance.
\end{abstract}

Keywords: Shanidar cave; Neanderthals; Neolithic; Bradost Mountain; Archeological site

\section{Introduction}

A geopark is a unified area that advances the protection and use of geological heritage in a sustainable way, and promotes the economic well-being of the people who live there (McKeever and Zouris, 2005). Geopark is that type of tourism that focused on the importance of geographical sites and showing the characteristics of the different geological features of the place from the natural, environmental and cultural points of view together with the human activities at that location (Errishi et al. 2020). There are two types of geoparks: 1) Global geoparks, and 2) National geoparks. A UNESCO definition of the global geopark is Geoparks are single, unified geographical areas where sites and landscapes of international geological significance are managed with a holistic concept of protection, education and sustainable development (Earth Sciences, 2019). Both types of geoparks are usually tourist sites where people like to visit for their particular interest which can be a special and rare geological character that is not a common feature. The presence of any significant geological feature in an area cannot be considered as a geopark unless it is recognized by UNESCO. After the park is recognized, then it will be considered as a National or Global Geopark. Shanidar cave has very interesting features, which cannot be found in the majority of the caves in Kurdistan Region, Iraq. The cave was inhabited in two-time intervals, the old was before 70000 years, whereas the recent one was before 10600 years. Moreover, the cave contains two later proto-Neolithic cemeteries, one of which DOI: $10.46717 /$ igj.54.1C.10Ms-2021-03-30 
dates back about 10,600 years and contains 35 individuals (Solecki et al. 2004). These two significant characters are very rarely found in one cave; therefore, the cave will be a significant geopark, when recognized by UNESCO and can be a very interesting site for archeologists and cave dwellers. Many works were carried out concerning Shanidar Cave but all of them were involved with its archeological findings of Neanderthal remains. Stewart (1963) mentioned about the discovered skeletons in the cave and gave a detailed description. Solecki (1975) was the first archeologist who discovered the remain of Neanderthals in the cave and gave a detailed description to the cave and the archeological discoveries. Erik (1983) and Edward (2010) gave a detailed description of the found skeletons in Shanidar Cave. Lietava (1992) mentioned about the medicinal plants found in the graves found in the cave. Sommer (1999) re-evaluated the Neanderthal Burial Ritual. Solecki et al. (2004) continued the archeological survey and mentioned the details of the discovered cemetery. Al-Ameri et al. (2011) reported about the cave in a report dealing with the Middle paleolithic to neolithic cultural history of North Iraq. Mohammad et al. (2017) mentioned the cave in a general report which deals with the cave animals in Iraqi Kurdistan Region. Eduljee (2019) mentioned about details of the Shanidar cave as a cave dweller. Sissakian (2019) mentioned about the details of the cave and presented the geological details of the cave and surrounding area.

\section{Location}

Shanidar cave is located $125 \mathrm{~km}$ north of Erbil city and $15 \mathrm{~km}$ northwest of Rawanduz town within Bradost Mountain (anticline) (Fig. 1). It can be reached directly via paved roads from either Erbil city or Aqra (Akre) town. The paved roads end at a large car park, then a series of stony leaders lead to the cave.

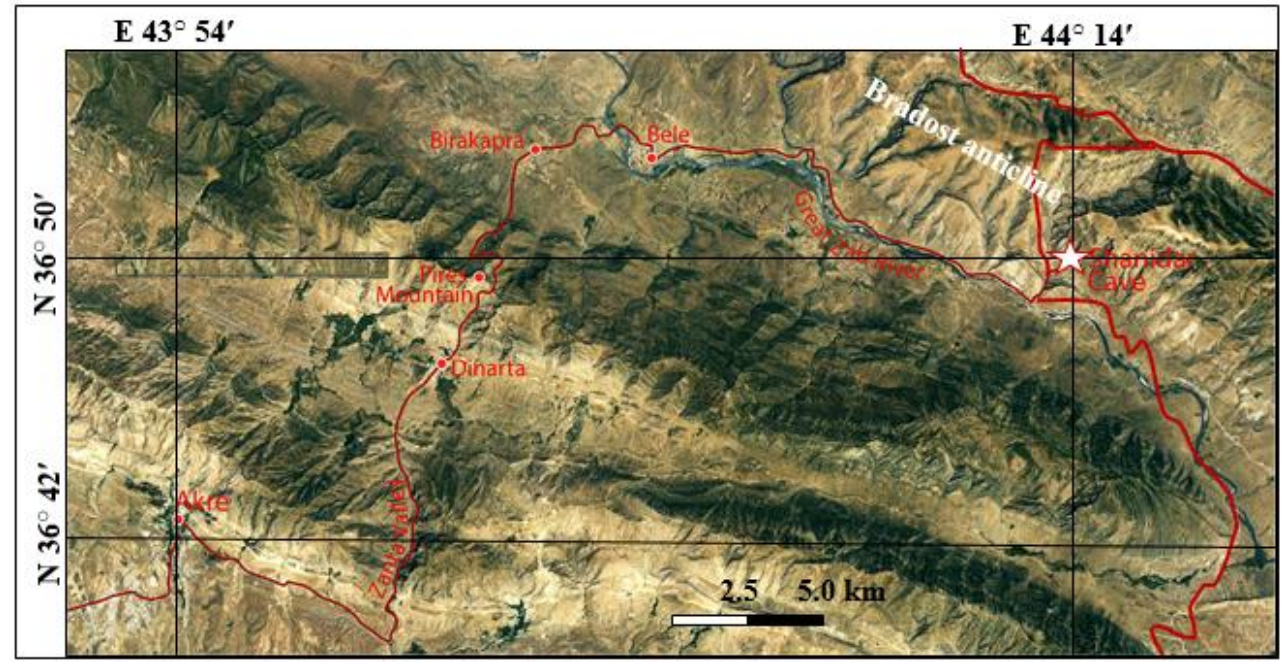

Fig.1. Satellite image of Shanidar Cave in Bradost Mountain (anticline)

\section{Materials and Methods}

To perform this work, the following materials were used:

- Geological maps at a scale of 1:100000 and 1:250000

- Satellite images showing Shanidar cave and surroundings

- Published articles and reports concerning the archeological site in the cave

- Interviewing persons interested in considering the cave as a national geopark

From the published articles and reports, the significance of the archeological site of Shanidar cave was studied. The geology of the concerned areas was studied from the published geological maps (Sissakian and Fouad, 2014; Fouad, 2012) and satellite images. Moreover, the cave was visited during 
2012 (Fig. 2) and 2019 to collect more geological data and information about the cave and surroundings; as the type of slopes, vegetation cover, beauty of the landscape which should be available in geoparks. As the recommended site to be a national geopark, representatives of many involved offices were met and the subject was discussed with them to acquire information about how far the procedure of considering the cave as a national geopark is gone.

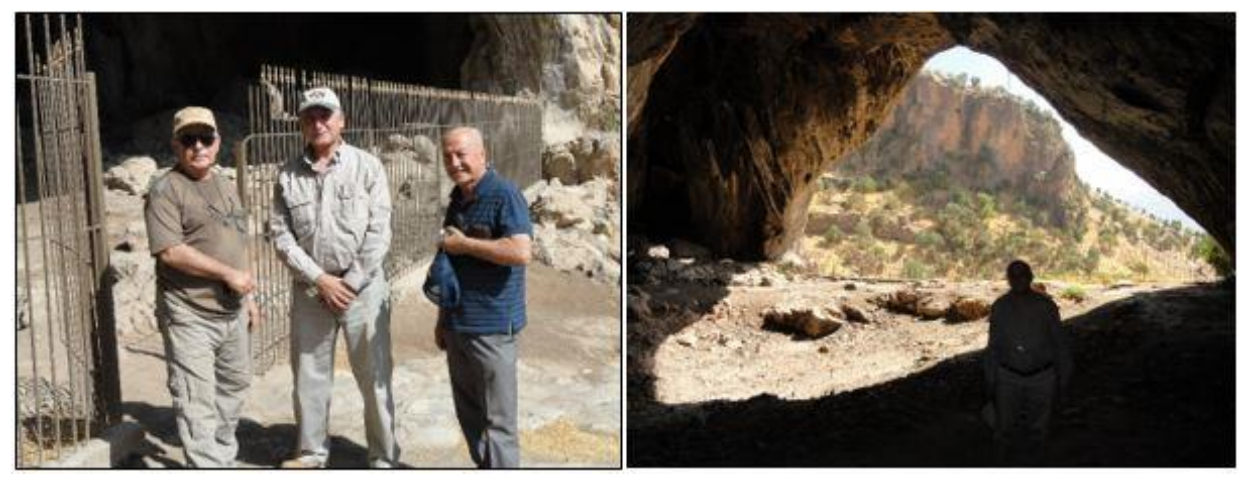

Fig.2. Shanidar cave; Left) A metallic door is fixed in the entrance, Right) A view from inside the cave towards outside, the excavated archeological trench is still observable

\section{Geological Setting}

Shanidar cave is located in Bradost anticline (mountain) which is a NW- SE trending anticline with many faults among them are two main thrust fault which run almost parallel to each other and have dissected the anticlinal axis twice (Fig. 3). The anticline shows clear three domes in which the Upper Jurassic formations (Chia Gara, Barsarin, Naokelekan and Sargelu) are exposed. The northwestern dome is dissected by the thrust fault too. The anticline shows steep asymmetry where the southwestern limb is very steep attaining $70^{\circ}$ (Fig. 4 Left), whereas the northeastern limb is gentle with a maximum dip amount of $12^{\circ}$ (Fig. 4 Right).

This complicated structural form of the anticline has accelerated the erosion and dissolution of the limestone beds which led to the development of Shanidar Cave. Shanidar Cave is developed within the Qamchuqa Formation of Lower Cretaceous age (Fig. 3). The formation consists of massive limestone and dolostone (Sissakian and Saeed, 2012), it is underlain by the Sarmord and/ or Balambo Formation (Sissakian and Mohammed, 2014) (Fig. 3), both include soft marl and shale beds (Sissakian and Saeed, 2012). The soft rocks were used by Neanderthal to bury the dead people.

The Qamchuqa Formation is overlain by the Bekhme Formation which consists of well thinly bedded limestone and dolostone. The Bekhme Formation is overlain by the Shiranish Formation which consists of well bedded white limestone overlain by thinly bedded greyish blue marl and limestone (Fig. 5 , Left).

The Shiranish Formation is overlain by the Tanjero Formation which consists of dark green sandstone, shale and claystone (Sissakian and Saeed, 2012 and Sissakian and Mohammed, 2014). These variations in the lithology, bedding thickness and rock colors give spectacular scenes to the slopes and cliffs of Bradost Mountain, especially the area surrounding Shanidar Cave (Figs. 4, 5 and 6, Left). Accordingly, encourage and increases the chance to recommend the cave as a national park besides its archeological significance. 


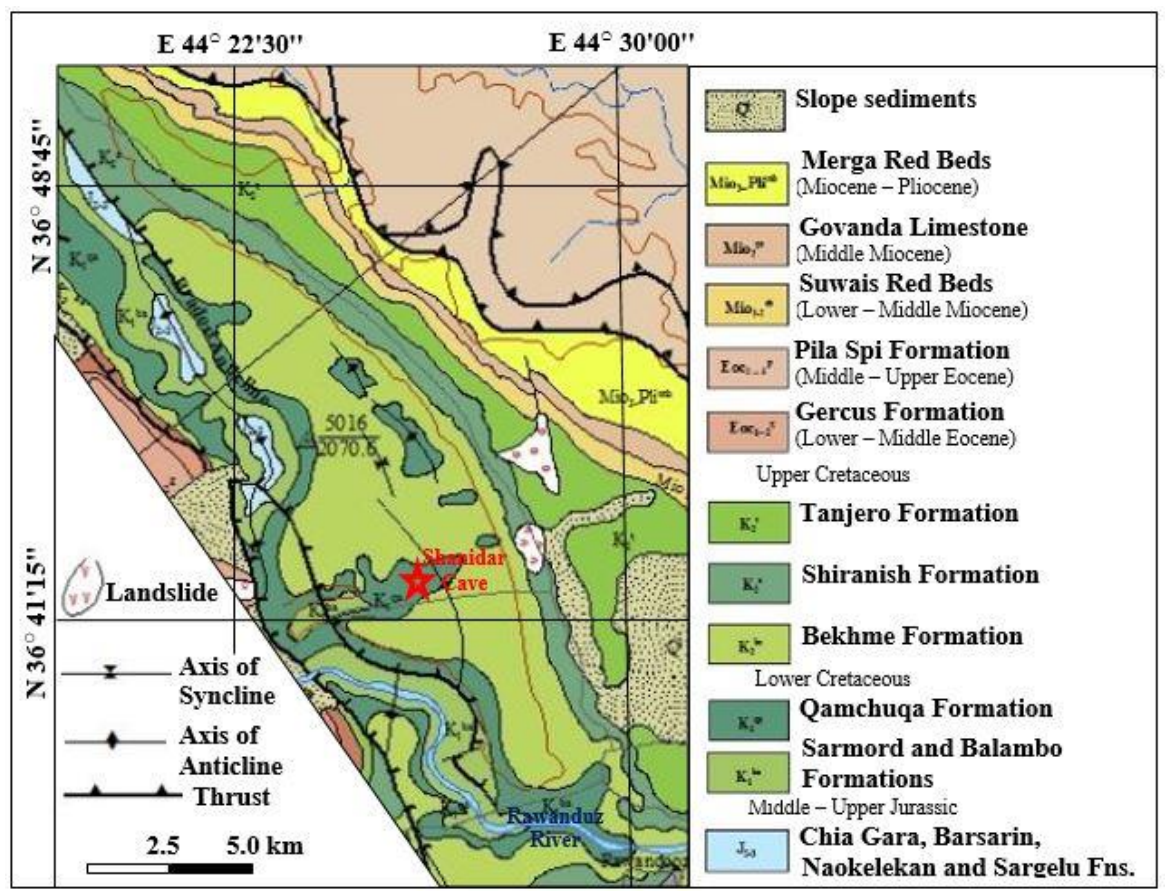

Fig.3. Geological map of Bradost anticline showing the location of Shanidar Cave (Modified from Sissakian and Fouad, 2014)

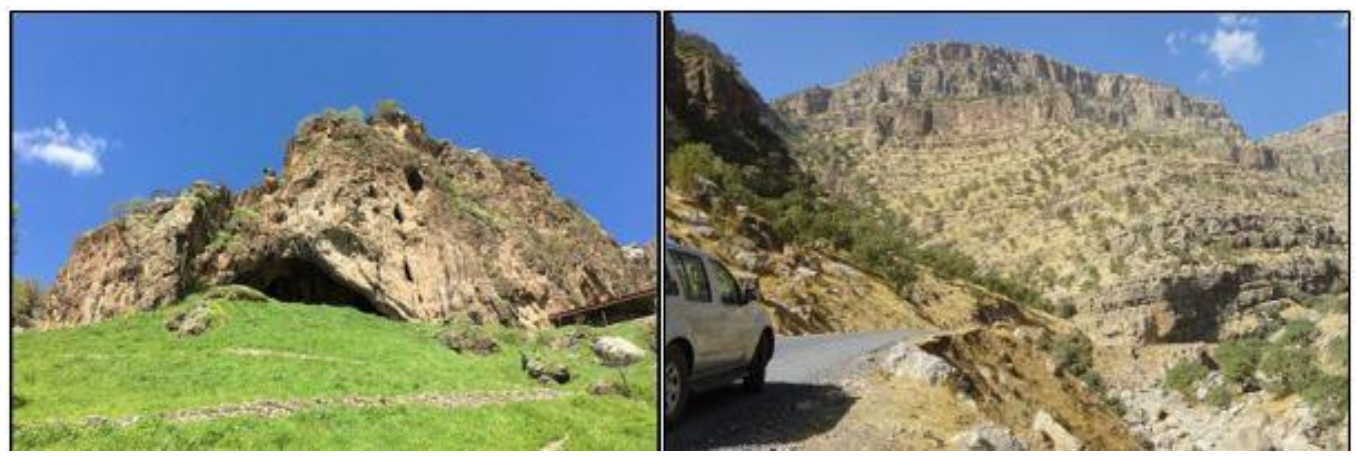

Fig. 4. Left) The entrance of the cave with steeply dipping beds, Right) The gently dipping beds in the northeastern limb of Bradost anticline

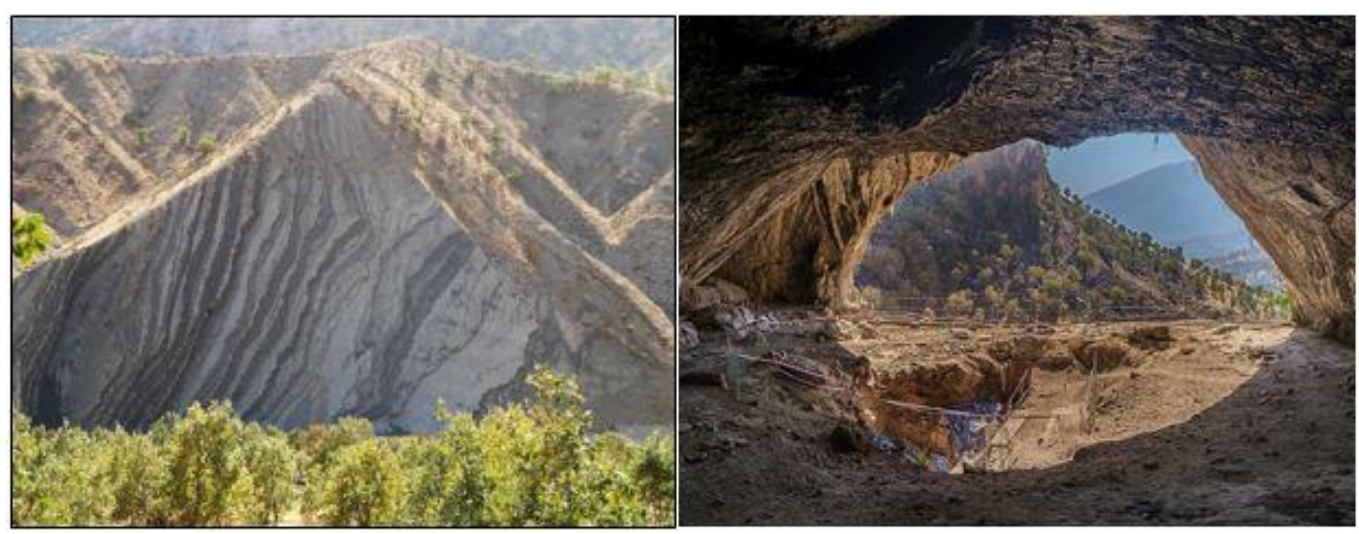

Fig. 5. Left) Interbedding of dark bluish grey and light grey marl beds of the Shiranish Formation, Right) The floor of Shanidar Cave, note the soft excavated beds during archeological discoveries (Photo from Solecki, 1975) 

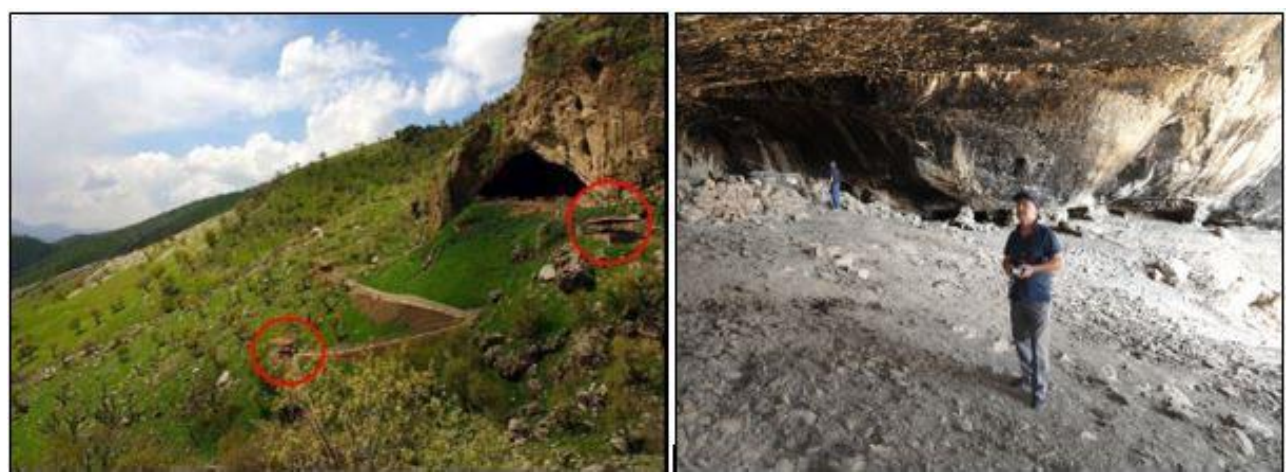

Fig.6. Shanidar Cave, Left) The entrance of the cave and part of the rocky leader with rest areas (encircled in red), Right) The dome shape of the cave

\section{Shanidar Cave}

\subsection{Characteristics of Shanidar Cave}

Shanidar Cave is developed within limestone beds of the Qamchuqa Formation in Bradost anticline (mountain). The entrance of the cave is at elevation of $737 \mathrm{~m}$ (a.s.l.) capped by very rugged cliffs which attain about $400 \mathrm{~m}$ in height (Figs. 1, 2 Right, 4 Left and 5 Right), whereas the slope along which the entrance is located has gradient of $44 \%$ (Fig. 6 Left). These topographic characters serve excellent defense site for the people who were living in the cave. The maximum height of the entrance of the cave is about $12 \mathrm{~m}$ (Figs. 2, 4 Right and 6 Left), with one large chamber almost of dome shape (Fig. 6 Right). In the floor of the cave, which is about $1070 \mathrm{~m} 2$ (Solecki, 1975) the excavation debris of archaeological studies can be seen (Figs. 2 Right and 5 Right).The cave can be reached via artificial ladder constructed from carbonate blocks of the Qamchuqa Formation with many rest stations constructed from woods of local trees (Fig. 6 Left). The height difference between the car park (Fig. 7 Left) and the cave's entrance is $450 \mathrm{~m}$. Two big holes and one small can be seen in the ceiling of the cave (Fig. 7, Right), they may be artificial for ventilation and/ or lighting by sun rays. Deep solution hole (sinkhole) exists in the floor of the cave with many steps (Fig. 8, Left). The hole was used during the archaeological excavation of the cave where remains of 12 bodies were found (Fig. 8 Right). They were called Shanidar I - XII (Solecki, 1975). The ceiling of the cave is covered by blackened by the soot of fires through the ages (Fig. 6 Right).

\subsection{Archeological Findings in Shanidar Cave}

A team from Columbia University in mid-1950's started discovering Shanidar Cave and found Neanderthal remains. Between 1953 and 1961, an archaeological team led by Smithsonian anthropologist Ralph Solecki discovered remains and artifacts that indicated Shanidar Cave had been inhabited by a small community of Neanderthals nearly 70,000 years ago (Fig. 9). In total 12 skeletons were discovered and were called Shanidar I - XII (Fig. 8 Right). The first nine skeletons were excavated between 1957 and 1961. The tenth skeleton was discovered in 2006 when an archeologist discovered several bones from the collection that did not match the others. Although Shanidar Cave was not the first location of Neanderthal skeleton discovery, but it was the first that shed light on the burial practices and causes of death among Neanderthals (Fig. 10) (Internet data, 2019). The cave also contains two later "proto-Neolithic" cemeteries, one of which dates back about 10,600 years and contains 35 individuals (Solecki et al. 2004). 


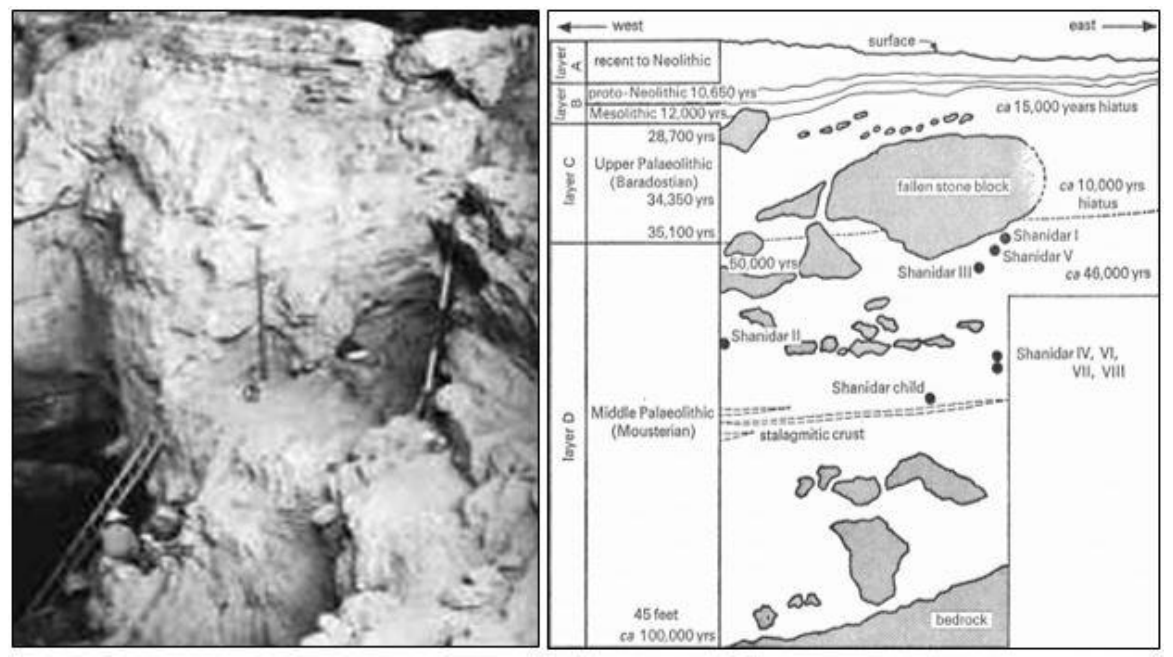

Fig.8. Left) The archeological excavations in Shanidar Cave. Note that the solution cave was used as the main living chamber by Neanderthals, it was discovered by the excavations, Right) A cross section of the excavated trench and location of the found skeletons (From Reynolds et al. 2015)

The constructed cross section (Fig. 8 Right) shows a fallen large stone from one of at least nine major rock-falls during the Middle Paleolithic age, covering a span of an estimated 40000 years, from 80000 to 40000 years ago. At least two of Shanidar Neanderthals were killed by rock fall. According to Solecki (1975), four major cultural horizons (periods) were identified in the $14 \mathrm{~m}$ deep excavation trench (Fig. 8). Layer A was a very dense occupational zone that included many bands of large and varicoloured hearth lenses with inclusion of animal bones, potsherds, and a great quantity of goat and sheep dung in its upper parts. There is also evidence of wide spread burning of animal dung. Layer D had the longest occupation and extended down to bedrock (Fig. 8 Right). It is in Layer D that nine skeletal remains were recovered.

The remains of a tenth individuals were identified later. The team dated the remains to the last Ice Age (65,000 to 35,000 years ago). Proto-Neolithic skeletal remains were also found in the back of the cave during the 1960 excavation season. Most of the individuals whose remains were discovered had been intentionally buried. However, three of the individuals appear to have been killed by rock-falls from the cave's ceiling (Fig. 8 Right). It is significant that the burials took place within the cave itself and that the bodies were not buried or disposed of outside the cave.

A Proto-Neolithic cemetery dating 10,600 years B.P. (in 1958) \pm 300 years was found in the right rear of the cave during 1960 season. It is then, that the skeletal remains of 35 individuals were recovered. In addition to the early human remains found, what made the discovery important was the recovery of burial goods associated with the burials (Reynolds et al., 2015).

\section{Geopark Recommendation}

The reasons for recommending Shanidar Cave to be a National Geopark with UNESCO consideration and the carried-out attempts are briefed below.

\subsection{Positive Reasons for Recommendation}

The positive reasons which encourage recommendation of Shanidar Cave to be considered as a National Geopark by UNESCO are:

- The unique and significant archeological findings in the cave, where for the first time the burial of Neanderthals were discovered.

- The cave was used by Neanderthal for more than one-time interval during Ice Ages. 
- The geological features including landscapes give to the surrounding area of the cave beautiful scenes.

- No any national geopark occurs in the whole Iraqi territory, whereas there are in Turkey, Iran and Saudi Arabia.

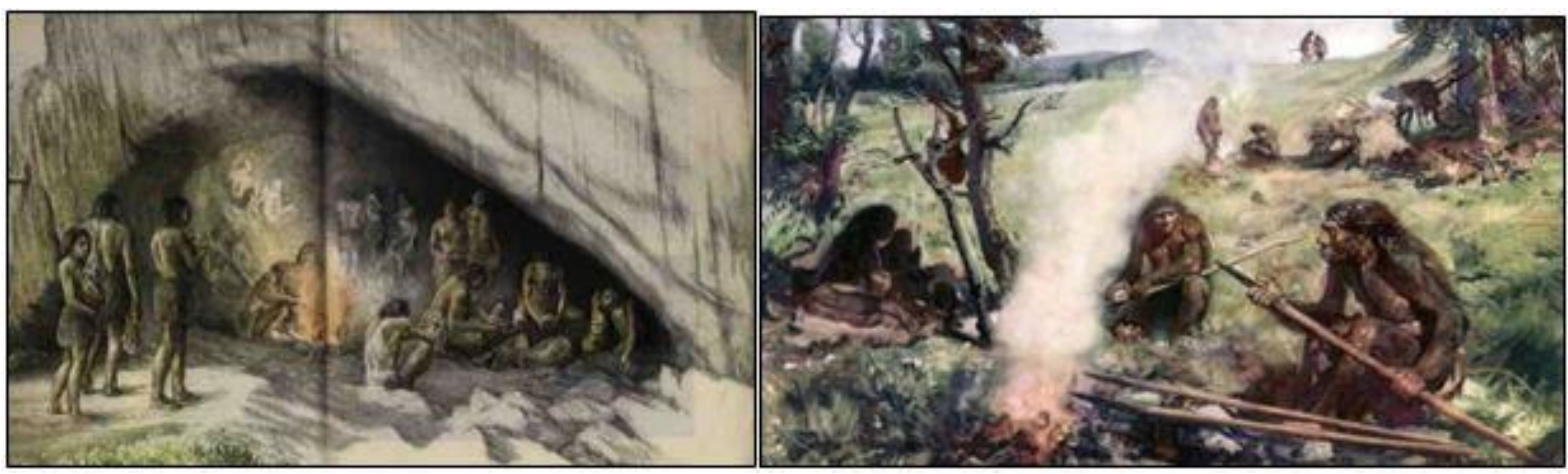

Fig.9. Artistic drawings expressing the life of Neanderthals (After Edward, 2010)
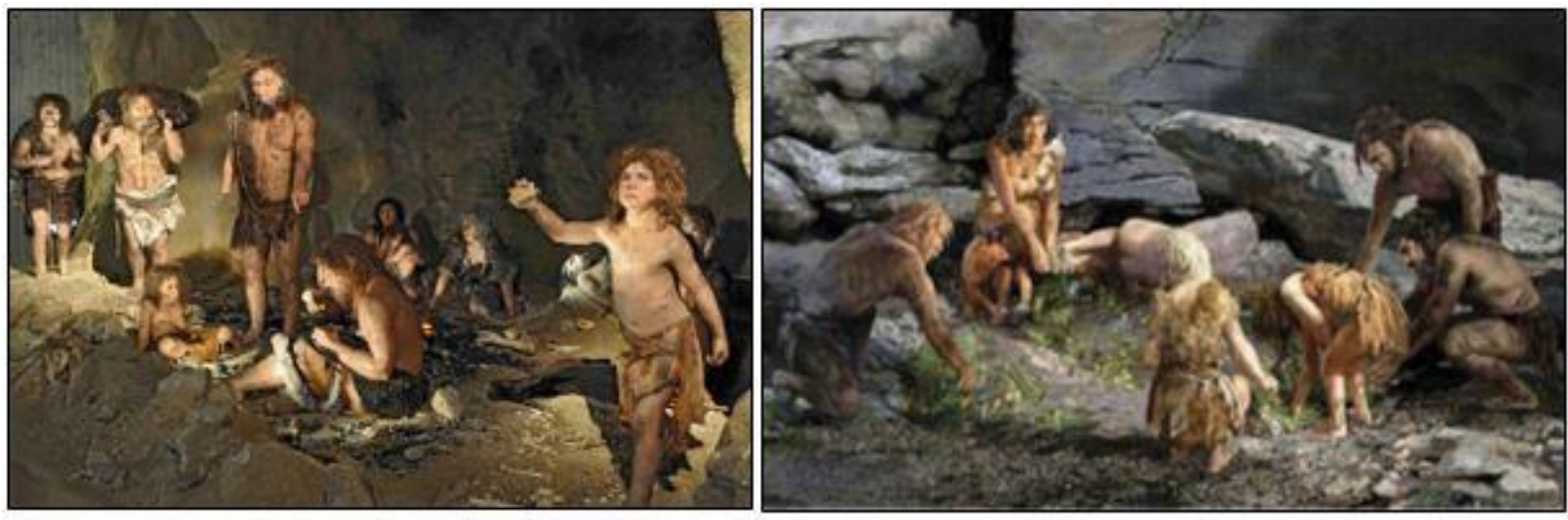

Fig.10. Spectacular drawing for burial ceremony in Shanidar cave. Note the flowers and other plants around the grave (After Edward, 2010)

\subsection{Carried out Attempts}

Different attempts were carried out to consider Shanidar Cave as a National Geopark and be recognized by UNESCO, but all carried out attempts were in vain hitherto due to different reasons. The attempts are:

- The Ministry of Environment tried to register the site as a National Geopark through the National Committee of Studying Natural Sites on 7th of September 2011 (Personal communication with Dr. Aqeel Al-Zubaidi 2015).

- The Kurdistan Institution for Strategic Studies and Scientific Researches located in Sulaimani, Iraqi Kurdistan Region tried to register the cave as a National Geopark during last decade (Personal communication with Prof. Dr. Polla Khanaqa, the President of the institution, 2012).

- The environment protection friends at Barzan area in Iraqi Kurdistan Region tried to register the cave as a National Geopark during this decade (Personal communications with Mr. Mohammed Barzani, a professional nature photographer). 


\section{Conclusions}

Shanidar Cave has positive reasons to be considered as a national geopark, among them are the archeological very interesting reasons including the burial of the dead Neanderthals and being used for different time intervals during Ice Ages. Moreover, the geological aspects including diversity in lithology, and landscapes, besides other natural beauty scenes.

\section{Recommendations}

Due to the aforementioned reasons, it is highly recommended to consider Shanidar Cave as a National Geopark by UNESCO. Moreover, to follow-up the already carried out attempts and contacting the involved authorities in UNESCO to fulfill the requirements and other needs to facilitate the recognition procedure. It is also recommended to add the following, which will facilitate the recognition procedure by UNESCO for the cave to be a National Geopark:

- Advertisements in media about the details of Shanidar Cave,

- Announcements to encourage tourism activities,

- Construction of relevant rest areas, restaurants, cafeterias near the site,

- Establishment of a special web site for the site including all details,

- Asking professional authorities inside and outside Iraq to continue the already carried out archeological studies, and

- To name the site as "Shanidar National Geopark".

\section{Acknowledgements}

The author would like to extend his sincerer thanks to Prof. Dr. Polla Khanaqa, Dr. Aqeel Al-Zubaidi and Mr. Mohammed Barzani for the supplied data as Shanidar Cave is considered and for their attempts to register the site as a national geopark and being recognized by UNESCO. The authors are very grateful to the Editor in Chief Prof. Dr. Salih M. Awadh, the Secretary of Journal Mr. Samir R. Hijab. and the Technical Editors for their great efforts and valuable comments.

\section{References}

Al-Ameri, T. K., Jasim., S.Y., Al-Khafaji, A. J. S., 2011. Middle paleolithic to neolithic cultural history of North Iraq. Arabian Journal of Geosciences, 4, 945-972.

Earth Sciences, 2019. UNESCO definition of Global Geopark. Internet data. http://www.unesco.org/new/en/natural-sciences/environment/earth-sciences/unesco-global-geoparks/.

Eduljee, K. E., 2019. Zoroastrian Heritage. Cave dwelling of Shanidar-heritageinstitute.com heritageinstitute.com/.../cavedwellings/shanidar.htm

Edward, O., 2010. The skeletons of Shanidar Cave. Smithsonian Magazine, March 2010. Retrieved 17 October 2014.

Erik, T., 1983. The Shanidar Neanderthals. Academic Press. ISBN 0-12-7005501.

Errishi, H., El-Ekhfifi, S. S., Muftah, A. M., Elseaiti, S. O., 2020. Highlights on the geotourism in Libyan desert, Iraqi Geological Journal, 53 (1B), 108-120.

Fouad, S. F., 2012. Tectonic Map pf Iraq, scale 1:1000000, 3rd edition. Iraq Geological Survey Publications, Baghdad, Iraq.

Internet data, 2019. Shanidar Cave. The Kurdish Project. thekurdishproject.org/.../shanidar-cave

Lietava, J., 1992. Medicinal plants in a middle paleolithic grave Shanidar IV, Journal of Ethnopharmacology, 35(2), 263-266.

McKeever, P.J., Zouros, N., 2005. Geoparks: Celebrating earth heritage, sustaining local communities. EPISODES, 274-278.

Mohammad, M. K., Afrasiab, S.R., Al-Zubaidi, A. A., Abdul-Rassoul, M. S., 2017. Survey for cave animals of Iraqi Kurdistan. Journal of Biodiversity and Environmental Sciences, 10(5), 217-232. 
Reynolds, T., Boismier, W., Farr, L., Hunt, C., Abdulmutalb, D., Graeme Barker, G., 2015. A review of world Archeology, ANTIQUITY, 89(384).

Sissakian, V. K., 2019. Shanidar Cave: An interesting archeological site in Iraqi Kurdistan Region, University of Kurdistan Hewler, Journal of Science and Engineering, 2(2), 1-9.

Sissakian, V. K., Saeed, Z. B., 2012. Lithological Map of Iraq, compiled using GIS Techniques. Iraqi Bulletin Geology and Minning, 8(3), 1-13.

Sissakian, V. K., Mohammed, B. S., 2014. Stratigraphy. In: The geology of the High Folded Zone, Iraq. Iraqi Bulletin Geology and Minning, 6, 73-161.

Sissakian, V. K., Fouad, S. F., 2014. Geological Map of Erbil and Mhabad Quadrangles, scale 1:250000, 2nd edition. Iraq Geological Survey Publications, Baghdad, Iraq.

Solecki, R. S., 1975. Shanidar IV, a Neanderthal Flower Burial in Northern Iraq, Science 190(4217), 880-881.

Solecki, R. S., Solecki, R.L., Agelarakis, A. P., 2004. The Proto-Neolithic Cemetery in Shanidar Cave. Texas A\&M University Press, p. 3-5.

Sommer, D. J., 1999. The Shanidar IV 'Flower Burial': A Re-evaluation of Neanderthal Burial Ritual. Cambridge Archaeological Journal, 9(1), 127-129.

Stewart, T. D., 1963. Shanidar Skeletons IV and VI. Sumer, 19, 8-26. 